\title{
Professionalism: The importance of trust
}

$\mathrm{P}$ atient trust in medicine is something of a paradox. Most patients consider their own doctors trustworthy. Yet public confidence in health care as a whole has been steadily eroding. This is a growing concern for many physicians, who believe regaining the public's trust in the field of medicine is a professional duty.

"In Britain, the medical profession is still the most trusted profession, though people are more likely to trust their doctors and not necessarily the system," says Dr. Donald Irvine, chairman of Picker Institute Europe, a nonprofit that promotes public health and medical education, and past president of the United Kingdom's national medical regulator, the General Medical Council.

Indeed, this appears to be the case in many countries. In the UK, $88 \%$ of adults trust their doctors to tell them the truth, putting them above teachers $(81 \%)$, professors $(74 \%)$ and all other occupations (www.ipsos-mori.com /Assets/Docs/Polls/Veracity2011.pdf). Physicians in the United States don't rank as high with respect to honesty and ethics; though they still do fairly well, placing third behind nurses and pharmacists (www.gallup.com/poll /1654/honesty-ethics-professions.aspx).

Surveys on trust and confidence in medical practice in general, however, tell a different story. A 2010 poll conducted by Angus Reid Public Opinion for Maclean's, for instance, found that, although most people believe their own doctors perform well, $40 \%$ of Canadians believe doctors care less about patients than a decade ago, and more than half believe doctors are reluctant to admit to their mistakes (http://www2.macleans.ca /2010/08/16/do-you-trust-your-doctor/).

Trust in the health care system in the UK may also be declining, though British research on trust in medicine tends to focus on interpersonal trust between physicians and patients rather than on trust of health systems and institutions, according to one paper on

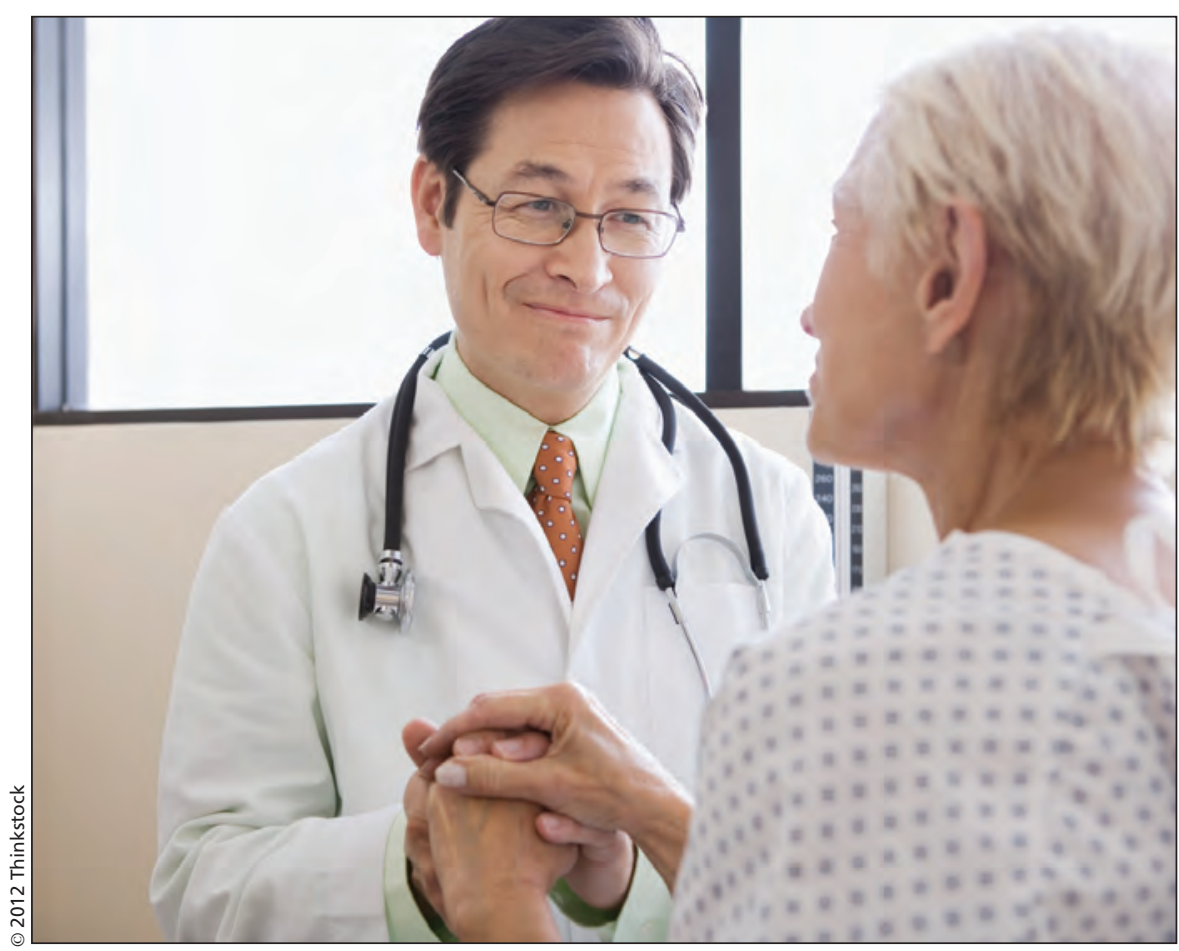

Without trust, physician-patient interactions could become little more than consumer transactions.

the subject ( $J$ Health Serv Res Policy 2008;13:97-103).

"There is much theoretical talk about a decline in trust in medicine, but empirical evidence to support this contention is difficult to find," the paper's lead author, Michael Calnan, professor of medical sociology at the University of Kent in Canterbury, England, writes in an email. "Our line is that peoples' beliefs/concepts about trust may have changed from a blind or assumed trust to a more conditional trust, although there are still high levels of trust in the medical profession, particularly in individuals as opposed to the institution. However, it must be emphasised that our data is from the National Health Service and trust might be more problematic in the context of a system, such as the one in the United States, where clinical judgements are more explicitly linked to financial incentives."

The creep of commercialism into medicine is commonly cited as a reason for declining trust of the medical profession as a whole. Doctors, after all, often have many ties to the pharmaceutical industry and conflicts of interest abound. Other reasons commonly cited include media scandals that uncover gross incompetence or the covering up of mistakes, physician strikes over purely financial matters, and general skepticism about the altruism of doctors, a trend that began decades ago and continues to this day.

Some physicians fear this lack of trust in medical practice can have severe consequences at high levels, and that this could eventually lead to problems in patient care. If the public is not on the side of doctors, after all, it is more likely that physician voices will go unheard in government policy decisions about health care.

"There are areas where physicians have expertise and should be listened to," says Dr. Richard Cruess, a professor of surgery at McGill University's 
Centre for Medical Education in Montréal, Quebec. "If we are not trusted as a profession, we are limited in our ability to provide input to public policy."

To ensure that public trust in the profession of medicine doesn't decline further, its members need to do more than just discuss the problem, says Cruess. They need to perform actions to reassure the public that doctors have the best interests of patients at heart. "The only way public trust will be maintained or increased by medical professionals is not by just projecting an image of concern for the welfare of society, but by acting, by actually helping society."

If the distrust at the profession level were to be translated to the individual physician level, many experts believe the doctor-patient relationship would suffer and, along with it, the health of patients. "Without trust, you can't really heal," says Dr. Sylvia Cruess, a professor of medicine at McGill University's Centre for Medical Education. "Would you let someone cut open your stomach for money rather than for your own good?"

Without trust, physician-patient interactions could become more like consumer transactions at a shopping mall. A patient might demand this test or that procedure and expect a physician to merely sign off on it. That might work in certain scenarios, but probably not in complex cases with many treatment options.
"There has to be an element of trust," says Dr. Sharon Johnston, assistant professor of family medicine at the University of Ottawa in Ontario. "If you have ever been really sick — really scared and vulnerable - you'd know there is no replacing it."

A long-term trusting relationship can benefit both physicians and patients, says Mary Dixon-Woods, professor of medical sociology at the University of Leicester in the UK. Doctors, who are human and make mistakes, receive more grace from patients, while patients appear more willing to follow through on recommended courses of treatment, she says. "Once that secure trust has been developed, patients are more forgiving of doctors' minor lapses. The quality of the relationship is also important to a patient's willingness to comply with what a doctor is suggesting." - Roger Collier, CMAJ

CMAJ 2012. DOI:10.1503/cmaj.109-4264

Editor's note: Eleventh in a multipart series on medical professionalism.

Part I: The "good doctor" discussion (www.cmaj.ca/lookup/doi/10.1503/cmaj .109-4200).

Part II: What is it? (www.cmaj.ca/lookup/doi/10.1503/cmaj.109-4211).

Part III: The historical contract (www.cmaj.ca/lookup/doi/10.1503/cmaj.109-4230).

Part IV: Can it be taught? (www.cmaj.ca/lookup/doi/10.1503/cmaj.109-4232).

Part V: Social media outreach (www.cmaj.ca/lookup/doi/10.1503/cmaj.109-4207).

Part VI: Social media mishaps (www.cmaj.ca/lookup/doi/10.1503/cmaj.109-4209).

Part VII: Logging on to tell your doctor off (www.cmaj.ca/lookup/doi/10.1503/cmaj .109-4205).

Part VIII: Assessing physician behaviour (www.cmaj.ca/lookup/doi/10.1503/cmaj .109-4240).

Part IX: How payment models affect physician behaviour (www.cmaj.ca/lookup /doi/10.1503/cmaj.109-4250).

Part X: The view from outside medicine (www.cmaj.ca/lookup/doi/10.1503/cmaj .109-4257).

\section{The fiendish puzzle of health inequities}

\section{$\mathrm{M}$} edieval cartographers once depicted monsters and bogs on the borders of their maps, as if foraying into uncharted territories put one at risk of unimaginable and unpredictable consequences.

It might be said that Canada's physicians find themselves in a bit of that predicament after embracing the notion that they have a major role to play in addressing health inequities and the social determinants of health, such as housing, education and poverty.

As they discovered during sessions of the Canadian Medical Association's 145th annual general meeting, held in
Yellowknife, Northwest Territories, the solutions aren't readily identifiable, and definitely not easily achieved. Broad policy solutions, like ones offered in a keynote lecture by internationally renowned epidemiologist Sir Michael Marmot, are not generally palatable to governments or consistent with prevailing political winds, while more local action, and even measures taken at the physician-patient level, can quickly devolve into classic conundrums.

Still, it's remarkable, in and of itself, that CMA's annual general meeting would even have health inequities as a conference theme. Just a few years ago, as a market research and strategic communications expert told delegates in 2009 , the public perception was that if the nation's physicians were speaking, the subject had to be the inadequacy of their compensation (www.cmaj.ca /lookup/doi/10.1503/cmaj.109-3021).

But with the election of Ottawa physician Dr. Jeffrey Turnbull to the CMA's presidency in August 2010, the association tacked sharply in the direction of civic responsibility, to the clear delight of many a physician, as delegate after delegate rose to their feet in Yellowknife to say they were proud that CMA was becoming more representa- 